\title{
Publisher Correction: Prominence of the tropics in the recent rise of global nitrogen pollution
}

\author{
Minjin Lee, Elena Shevliakova, Charles A. Stock, Sergey Malyshev \& P.C.D. Milly
}

Correction to: Nature Communications https://doi.org/10.1038/s41467-019-09468-4, published online 29 March 2019.

The original version of this Article contained errors in the References.

The citation currently given as reference [13] was previously incorrectly given as reference [14], and vice versa.

The citation currently given as reference [31] was previously incorrectly given as reference [37]. As a consequence of this, current references [32-37] were previously incorrectly numbered [31-36], respectively.

This has been corrected in both the PDF and HTML versions of the Article.

Published online: 04 December 2019

\begin{abstract}
(c) Open Access This article is licensed under a Creative Commons Attribution 4.0 International License, which permits use, sharing, adaptation, distribution and Ceproduction in any medium or format, as long as you give appropriate credit to the original author(s) and the source, provide a link to the Creative Commons license, and indicate if changes were made. The images or other third party material in this article are included in the article's Creative Commons license, unless indicated otherwise in a credit line to the material. If material is not included in the article's Creative Commons license and your intended use is not permitted by statutory regulation or exceeds the permitted use, you will need to obtain permission directly from the copyright holder. To view a copy of this license, visit http://creativecommons.org/licenses/by/4.0/.
\end{abstract}

(c) The Author(s) 2019 